\title{
Endometrial cytology, biopsy, and bacteriology for the diagnosis of subclinical endometritis in grazing dairy cows
}

\author{
L. V. Madoz, ${ }^{*} \dagger$ M. J. Giuliodori, $\ddagger$ A. L. Migliorisi, ${ }^{*}$ M. Jaureguiberry, ${ }^{*}$ and R. L. de la Sota ${ }^{*}{ }^{1}$ \\ *Laboratorio y Servicio de Reproducción Animal, Facultad de Ciencias Veterinarias-Universidad Nacional de La Plata (FCV-UNLP), La Plata, \\ B1900AVW, Argentina \\ †Consejo Nacional de Investigaciones Científicas y Técnicas (CONICET), Buenos Aires, C1033AAJ, Argentina \\ ¥Cátedra de Fisiología, FCV-UNLP, La Plata, B1900AVW, Argentina
}

\begin{abstract}
The objectives of this study were to assess the agreement between endometrial cytology and uterine biopsy for the diagnosis of subclinical endometritis (SEND) in grazing dairy cows, the interobserver agreement of the biopsy's readings, and the bacterial population isolated from the uterus of cows having SEND. In experiment 1, lactating Holstein cows $(\mathrm{n}=44) 31$ to $59 \mathrm{~d}$ in milk (DIM) at sampling were enrolled. Clinical endometritis was diagnosed by direct evaluation of vaginal discharge and SEND by endometrial cytology evaluation. Two hundred cells per smear were counted to determine the percentage of polymorphonuclear neutrophilic leukocytes (PMNL). Cut-off values used were $\geq 8 \%$ PMNL at $\leq 33$ DIM, $\geq 6 \%$ PMNL at 34 to 47 DIM, and $\geq 4 \%$ PMNL at $\geq 48$ DIM. Biopsies were assessed blindly by 2 observers who categorized them into 4 groups according to their inflammatory changes: none, minimal, moderate, and severe inflammatory changes. Data were analyzed using the kappa coefficient and logistic regression. In experiment 2 , lactating Holstein cows $(\mathrm{n}=60)$ 21 to 62 DIM were enrolled. Clinical endometritis and SEND were diagnosed as previously described. Samples were cultured for aerobic and anaerobic bacteria by routine methods of bacteriological testing. Data were analyzed with logistic regression. In experiment 1, little agreement was observed between cytology and biopsy outputs (kappa $=0.151)$, and strong agreement between the 2 operators $($ kappa $=0.854)$. The likelihood of having a normal biopsy (no inflammatory change) was greater for healthy cows than for those having SEND (odds ratio $=13.145)$. The probability for getting normal uterine tissue decreased $2.1 \%$ for every increasing percentage point in PMNL. In experiment 2, no bacteria were isolated from cows with SEND, coagulase-negative staphylococci were commonly isolated from healthy cows, and Trueperella pyogenes was frequently isolated
\end{abstract}

Received March 20, 2013.

Accepted September 5, 2013.

${ }^{1}$ Corresponding author: dairydoc $82 @$ gmail.com from cows with clinical endometritis. The likelihood of isolating $T$. pyogenes from uterine samples increased with the percentage of PMNL (odds ratio $=1.100$ ). In conclusion, biopsy showed low agreement with cytology for the diagnosis of SEND. Nevertheless, fertility trials using uterine biopsies to predict pregnancy outcomes are needed to determine its diagnostic usefulness. Finally, bacteriology would not be recommended as a diagnostic tool because no bacteria were isolated from cows with SEND.

Key words: dairy cow, subclinical endometritis, uterine biopsy, bacteriology

\section{INTRODUCTION}

Subclinical endometritis (SEND) was first described as cytological endometritis considering the presence of PMNL in the endometrial lumen (Gilbert et al., 1998), and then standardized by Kasimanickam et al. (2004) based on its negative effects on reproductive performance. Thus, those authors stated a threshold of percentage of PMNL, above which animals are diagnosed as having SEND and below which as not having it. Since then, some studies have shown that SEND is a common disease in postpartum dairy cows highly associated with poor reproductive performance (Kasimanickam et al., 2004; Gilbert et al., 2005). No gold standard exists for the diagnosis of SEND, which turns the task into a challenging one. Nevertheless, uterine cytological evaluation is the most used tool for SEND diagnosis (Kasimanickam et al., 2005). Cytobrushing is considered the best technique for obtaining endometrial cytological samples because it is easy and quick to perform (Barlund et al., 2008; Kasimanickam et al., 2005), and it is also safe and effective (Oral et al., 2009).

Other tools used for the diagnosis of uterine diseases in large animals are biopsy and bacteriology (Studer and Morrow, 1978; Dubuc et al., 2010). Uterine biopsies were used initially for the study of infertility in mares (Chapwanya et al., 2010) to predict the ability of the mare to conceive and carry out a new pregnancy (Kenney, 1978). Biopsy provides detailed information about 
uterine health status, and a 4-point scale has been developed for use in cows (Chapwanya et al., 2009) but, as far as we know, studies are still lacking relating biopsy scores with future fertility of the cow. In addition, only 1 work exists evaluating its use as a diagnostic tool for SEND (Meira et al., 2012).

On the other hand, several bacteriological studies have shown that metritis and clinical endometritis in cows (Messier et al., 1984; Williams et al., 2005; Santos et al., 2010; Westermann et al., 2010) are related to nonspecific mixed infections involving environmental bacteria (Rutter et al., 1999; Sheldon et al., 2002; Petit et al., 2009) that invade the uterus at parturition and immediately after it. Among bacterial species causing endometrial diseases, Trueperella pyogenes (formerly Arcanobacterium pyogenes) and Escherichia coli are the most prevalent, but Prevotella melaninogenica, Proteus spp., and Fusobacterium necrophorum have also been reported (Griffin et al., 1974; Williams et al., 2005). So, it is logical to expect the same bacteria to be involved in the pathogenesis of SEND. Whereas several bacteriological studies were carried out in the past to investigate the pathogenesis of puerperal metritis and clinical endometritis (Silva et al., 2009; Bicalho et al., 2010, 2012; Sheldon et al., 2010), to our knowledge, only a few bacteriological studies have been carried out in this regard on SEND, with no conclusive results (McDougall et al., 2011; Barański et al., 2012).

In summary, information is lacking about the usefulness of uterine biopsy for SEND diagnosis and about bacterial population involved in SEND cases in postpartum dairy cows. Therefore, the main hypotheses to test were that a correlation exists between diagnostic outputs obtained by both cytology and biopsy, that high repeatability and agreement exist between biopsy readings, and that the bacterial population involved in subclinical cases is similar to that found in clinical endometritis. So, the objectives of this study were to assess (1) the agreement between endometrial cytology (obtained by cytobrush) and uterine biopsy for the diagnosis of SEND in grazing dairy cows, (2) the interobserver agreement of the biopsy readings, and (3) the bacterial populations isolated from the uterus of cows having SEND.

\section{MATERIALS AND METHODS}

\section{Experiment 1}

Animals and Evaluation of Vaginal Discharge. The study was performed in the experimental dairy farm of the National University of La Plata (Lomas de Zamora, province of Buenos Aires, Argentina; $34^{\circ} 75^{\prime}$ S, $58^{\circ} 46^{\prime} \mathrm{W}$ ) where 44 lactating Holstein cows 31 to 59
DIM at sampling were enrolled. Cows with BCS $<2.5$ (5-point scale with 0.25 increments; Ferguson et al. (1994), retention of fetal membranes, abortion, or with intrauterine or systemic treatments were excluded from the study. Manual examination of the vagina and withdrawal of the mucus by a gloved hand for direct inspection was performed in all cows. Vaginal discharge (VD) was classified as normal clear discharge (VD-0); clear discharge with flecks of pus (VD-1); mucopurulent, not fetid discharge (VD-2); or purulent or brown-colored, and fetid (VD-3; Williams et al., 2005). Clinical endometritis was declared in cows having VD-1 through -3 .

Cytological Evaluation. Samples of endometrial cytology were collected using a cytobrush modified for use in cattle (Madoz et al., 2013). Briefly, a stainless steel device was attached with a sterile brush (Medibrush XL; Medical Engineering Co. SA, Buenos Aires, Argentina). The device was covered for protection from vaginal contamination with a bovine split universal sheath (IMV Technologies, Paris, France). Once the cervix was passed, the cytobrush was exposed and rolled into the endometrium and then covered again with the protective sheath. Outside the vagina, the cytobrush was removed from the pistol grip and rotated on a microscopic slide. Smears were fixed with spray (Roby; Argencos SA, San Martín, Argentina) to preserve cellular morphology and stained (Tinción 15; Biopur S.r.l., Rosario, Argentina). Evaluations were performed under a microscope at $400 \times$ magnification, where 200 cells were counted to determine the percentages of PMNL. Cut-off values for the diagnosis of SEND were $\geq 8 \%$ PMNL at 21 to 33 DIM, $\geq 6 \%$ PMNL at 34 to 47 DIM, and $\geq 4 \%$ at 48 to 62 DIM (Madoz et al., 2013).

Uterine Biopsy. Samples of endometrial tissue were collected using a stainless steel biopsy instrument 53 $\mathrm{cm}$ in length, having a jaw with cutting edges of $0.6 \times$ $0.4 \mathrm{~cm}$ (Chapwanya et al., 2010). Once the cervix was passed, the device's jaw was opened into the uterine horn and then the jaw was closed and rotated 90 degrees to obtain an endometrial tissue sample. Then, the device was removed from the cow and the sample was placed in a $1.5-\mathrm{mL}$ tube containing a $10 \%$ formaldehyde buffered solution; then, formalin-fixed tissues were dehydrated through a graded series of ethanol solutions, cleared in acetone, paraffin-embedded, sectioned at 5to $6-\mu \mathrm{m}$ thickness, and stained with hematoxylin and eosin. Later, they were evaluated under a microscope at $400 \times$ magnification and scored, independently of clinical findings, by the grades of endometrial inflammatory infiltrates. All biopsies were assessed by 2 observers blinded to the cows' identification and categorized with a simplified scale described by Chapwanya et al. (2009), using the following categories: $0=$ uterus with no inflammatory infiltrate (UB-0), $1=$ minimal inflamma- 
tion characterized by a low grade of lymphocytic and PMNL infiltration (UB-1), 2 = moderate inflammatory changes characterized by prominent lymphocytic and PMNL infiltration (UB-2), and $3=$ severe inflammation characterized by a high grade of monocytes and PMNL infiltration (UB-3). A cow was considered healthy just if presenting UB-0.

Statistical Analysis. The cow was considered the experimental unit. Agreement between diagnostic outcomes from cytology (SEND: yes vs. no) and uterine biopsy (SEND: yes vs. no) were evaluated by the kappa coefficient with PROC FREQ of SAS (SAS 9.1; SAS Institute Inc., Cary, NC). Interobserver agreement was evaluated by the weighted kappa coefficient with PROC FREQ. The likelihood of getting normal uterine tissue, defined as UB-0, was analyzed with PROC GENMOD (SAS 9.1) by using a binomial distribution (UB-0 vs. $\mathrm{UB} \geq 1$ ) and logit link function, and by including the fixed effect of SEND (yes vs. no) in model 1 and the percentage of PMNL as a continuous variable in model 2. The following equation: odds ratio (OR) percentage $=(\mathrm{OR}-1) \times 100$ was used to transform OR for continuous predictors into percentages (Allison, 1999). The equation: $\beta \times \operatorname{Pi}(1-\mathrm{Pi})$ was used to correct $\mathrm{OR}$ (Allison, 1999), where $\beta$ is the regression coefficient for the predictor and $\mathrm{Pi}$ is the probability of the event. Statistical significance was set at $P \leq 0.05$, and a trend for significance was set at $P \leq 0.10$ and $>0.05$.

\section{Experiment 2}

Animals. The study was performed in a commercial dairy farm located in Marcos Paz (province of Buenos Aires, Argentina; $34^{\circ} 56^{\prime} \mathrm{S}, 58^{\circ} 47^{\prime} \mathrm{W}$ ) where 60 lactating Holstein cows between 21 to 62 DIM were enrolled. Exclusion criteria included cows receiving antibiotics that would have the potential for distorting the bacterial isolations.

VD, Uterine Cytology, and Bacteriology. Clinical and SEND were diagnosed through VD and endometrial cytology evaluation as previously described in experiment 1. Samples used for bacteriological diagnosis were obtained from healthy cows (i.e., VD-0 and negative cytology evaluation), from cows with SEND (i.e., VD-0 and positive cytology evaluation), and also from cows with clinical endometritis (i.e., VD-1, -2, and -3) that acted as positive controls. These samples were obtained by a similar procedure to that described for uterine cytology with the addition of an extra cover sheath to avoid brush contamination. Then, brushes were placed in plastic tubes containing Stuart's transporting media (Eurotubo; Deltalab SL, Barcelona, Spain). Tubes were kept in an insulated container with transportation freezer packages until delivered within
$6 \mathrm{~h}$ at the Bacteriology Laboratory (Faculty of Veterinary Science, National University of La Plata, La Plata, Argentina) for processing. Bacteriological samples were cultured for aerobic and anaerobic bacteria by routine methods of bacteriological testing. Briefly, each brush was streaked in aerobic culture at $37^{\circ} \mathrm{C}$ for $48 \mathrm{~h}$ on plates containing sheep blood agar (Laboratorios Britania, Buenos Aires, Argentina) and in anaerobic culture in an anaerobic atmosphere with 5\% carbon dioxide, $10 \%$ hydrogen, and 85\% nitrogen (Hirayama Anaerorator; Hirayama Manufacturing Corp., Kasukabe, Japan) for up to 9 d on Brucella agar (Laboratorios Britania) with the addition of yeast extract (Oxoid Ltd., Basingstoke, UK), hemin solution $(5 \mathrm{mg} / \mathrm{mL}$; MP Biomedicals Inc., Strasbourg, France), vitamin K (1 mg/mL; Fluka, BioChemika, Barcelona, Spain), and laked blood. Bacteria were identified based on colony characteristic, Gram staining, morphology, hemolytic ability, and biochemical profile according to Winn et al. (2006).

Statistical Analysis. The likelihood of isolating uterine pathogens from uterine samples was analyzed with PROC GENMOD of SAS by using a binomial distribution (negative vs. positive) and logit link function, and by including the fixed effect of uterine health status (healthy vs. SEND vs. clinical endometritis) in model 1 , and the percentage of PMNL as a continuous variable in model 2 .

\section{RESULTS}

\section{Experiment 1}

Data from 7 out of 44 cows were excluded because biopsy samples were unreadable; therefore, the results of 37 cows were included in the statistical analysis. The agreement between cytology and biopsy outputs had a kappa coefficient of $0.151(P=0.27)$, and between the 2 operators' biopsy readings had a weighted kappa coefficient of $0.854(P<0.001)$. From healthy cows, $40.7 \%$ had UB-0 (11/27), 56\% had UB-1 (15/27), and $4 \%$ had UB-2 (1/27). From cows with SEND, $75 \%$ had UB-1 (3/4) and 25\% had UB-2 (1/4). Finally, from cows with clinical endometritis, $33 \%$ had UB-1 (2/6), $50 \%$ had UB-2 (3/6), and $16.7 \%$ had UB-3 (1/6). No cow having SEND or clinical endometritis had UB-0. The likelihood of having a normal biopsy was higher for healthy cows than for those having SEND (adjusted $\mathrm{OR}=13.145,95 \% \mathrm{CI}=2.935-58.876 ; P<0.001)$. In model 2 , the likelihood of having a normal uterine biopsy decreased $(P=0.031)$ by $2.1 \%$ for every 1 percentage point increase in PMNL.

\section{Experiment 2}

Seventy-three percent of cows $(44 / 60)$ had VD-0, $12 \%(7 / 60)$ had VD-1, and 15\% (9/60) had VD-2. No 
cow was found with VD-3. Therefore, the prevalence of clinical endometritis was $27 \%(16 / 60)$. Surprisingly, some cows having clinical endometritis were negative for SEND according to cytological evaluation [28\% $(2 / 7)$ for VD-1 and 33\% (3/9) for those having VD-2]. Finally, the prevalence of SEND was $14 \%$ (6/44 cows having VD-0).

No bacteria were isolated from cows with SEND, whereas CNS, Citrobacter spp., Micrococcus spp., Peptostreptococcus spp., and nonfermenter gram-negative bacilli were isolated from healthy cows (Table 1). In the case of cows with clinical endometritis, the bacteria isolated were $T$. pyogenes in cows having VD-2 and CNS (Table 1). Finally, the likelihood of isolating $T$. pyogenes from uterine samples increased $0.6 \%$ for every increasing percentage point in the percentage of $\mathrm{PMNL}$ $(P=0.003)$.

\section{DISCUSSION}

One of the hypotheses to test in this study was that a correlation exists between diagnostic outputs obtained by both cytology and biopsy. Contrary to our expectations, we found a low degree of agreement between the 2 diagnostic techniques (kappa $=0.151$ ). Biopsy provides valuable detailed information about uterine tissue inflammation in cows (Meira et al., 2012). It is used to assess the histological status of the entire endometrial layers, whereas cytology is used to evaluate only the superficial layer. So, by using biopsy, one could detect the varying degree of infiltration of PMNL and lymphocytes occurring during the estrous cycle (Studer and Morrow, 1978). Conversely, as the superficial endometrial layer does not change significantly during the estrous cycle (Madoz et al., 2013), by using cytology, one could not detect the dynamics of immune cell infiltration during the estrous cycle. That is, the biopsy output would be influenced by the estrous cycle, whereas the cytology output would not. In a recent study, it was found that biopsy had a sensitivity of 0.44 , a specificity of 0.92 , and a kappa of 0.39 when compared with uterine cytology for the diagnosis of SEND in dairy cows (Meira et al., 2012). It is important to note that cows in the present study were not estrus synchronized and were sampled only once, which did not allow us to evaluate physiological changes in immune cell infiltration during the estrous cycle. Also, this experimental design could have increased variability in both biopsy and cytology readings. Therefore, this study limitation could be another reason for the low agreement found between the 2 diagnostic techniques. Despite this low agreement, we found that an association existed between biopsy output and the uterine health status of the cow. Thus, the likelihood of having a normal tissue biopsy is 13 times higher in healthy cows than in herd mates having SEND. We also found that this likelihood decreased $2.1 \%$ for every increasing percentage point in PMNL (model 2). So, according to our data, biopsy would not be as useful for the diagnosis of SEND in the cow as it is reported to be in the mare, where it is used to evaluate the uterine ability to receive an embryo and to maintain a full-term pregnancy (Buergelt, 1997; Trigo Tavera, 1998). Although cytology is commonly used to diagnose SEND, it is not the gold standard to define SEND. So, the lack of agreement between both techniques does not rule out biopsy as a diagnostic tool. Therefore, uterine biopsy as a reproductive tool deserves further exploration in a controlled study in which the risk of becoming pregnant and maintaining a pregnancy are evaluated according to different biopsy scores.

Another hypothesis to test was that the bacterial population involved in subclinical cases is similar to

Table 1. Bacterial population isolated from healthy dairy cows and from cows with subclinical and clinical endometritis

\begin{tabular}{|c|c|c|c|}
\hline \multirow[b]{2}{*}{ Item } & \multicolumn{3}{|c|}{ Diagnosis, \% (no./total no.) } \\
\hline & Healthy $^{1}$ & SEND $^{2}$ & $\mathrm{CE}^{3}$ \\
\hline \multicolumn{4}{|l|}{ Bacteria } \\
\hline Trueperella pyogenes & $0(0 / 38)$ & $0(0 / 6)$ & $25.0(4 / 16)$ \\
\hline CNS & $10.5(4 / 38)$ & $0(0 / 6)$ & $12.5(2 / 16)$ \\
\hline Citrobacter spp. & $2.6(1 / 38)$ & $0(0 / 6)$ & $0(0 / 16)$ \\
\hline Micrococcus spp. & $2.6(1 / 38)$ & $0(0 / 6)$ & $0(0 / 16)$ \\
\hline Nonfermenter gram-negative bacilli & $5.3(2 / 38)$ & $0(0 / 6)$ & $0(0 / 16)$ \\
\hline Peptostreptococcus spp. & $2.6(1 / 38)$ & $0(0 / 6)$ & $0(0 / 16)$ \\
\hline No isolation & $76.3(29 / 38)$ & $100(6 / 6)$ & $62.5(10 / 16)$ \\
\hline
\end{tabular}


that found in clinical endometritis cases. It is widely accepted that uterine inflammation begins with bacterial contamination of the lumen at the time of parturition, involving nonspecific infections caused by a large number of bacteria (Williams et al., 2005). In cows with SEND, no isolation was obtained, whereas CNS were frequently isolated together with other bacteria in healthy cows. In endometritic cows, T. pyogenes, a recognized uterine pathogen (Werner et al., 2012), was detected in most of the cases. Our findings in healthy and endometritic cows are in agreement with recent metagenomic studies of uterine microbiota, showing that large microbial diversity can be identified in the uterus of dairy cows, irrespective of their uterine health status (Santos et al., 2011; Santos and Bicalho, 2012). Contrary to what we hypothesized, we failed to isolate any aerobic or anaerobic bacteria from cows having SEND. One possible explanation would be that by the time SEND was diagnosed, bacteria might have already been cleared from the uterus by host defense mechanisms occurring while the inflammatory response was still under way, restoring the normal uterine environment. This finding is in agreement with Barański et al. (2012), who postulated that the percentage of PMNL above the threshold for SEND is more related to uterine involution and recovery than to uterine bacterial infection. Also, in another investigation, a low level of agreement between the presence of intrauterine pathogens and the percentage of PMNL was found (McDougall et al., 2011). Another possible explanation could be that the detected uterine inflammation might be caused by another kind of microorganism, such as fungi (Jeremejeva et al., 2010). It is also possible that the reduced number of cows having SEND could have diminished the chances of getting bacterial isolations from those cows, which is one of the limitations of the present study. Finally, as this study was performed by traditional culture methods instead of by more sophisticated culture-independent methods (Rondon et al., 2000; Santos et al., 2011), it is possible that bacteria remained unseen in our SEND cows, probably hidden behind inconspicuous cell morphologies, increasing the number of uterine samples without isolation. In this sense, some progress has recently been achieved by using culture-independent methods to study virulence factors of bacteria in cows having metritis and endometritis (Silva et al., 2009; Bicalho et al., 2010, 2012; Sheldon et al., 2010; Santos and Bicalho, 2012). However, to the authors' knowledge, no study using culture-independent methods exists that reports the unseen bacterial population in cows with SEND.

The percentage of cows detected with SEND (14\%) in the current study is in agreement with recently reported prevalences of $17 \%$ (Madoz et al., 2013) and
13\% (Ribeiro et al., 2013) for grazing cows, but it is much lower than what is mentioned by most of the published papers (Raab et al., 2004; Gilbert et al., 2005; Kasimanickam et al., 2005; Hammon et al., 2006; Galvão et al., 2009; Plöntzke et al., 2010). Madoz et al. (2013) proposed that as grazing dairy cows have lower milk production than confined cows, they would face less marked metabolic stress during early lactation and would be able to better cope with the elimination of uterine bacterial contamination, leading to lower endometritis prevalence in grazing cows. Another explanation could be that as cows with low BCS, retention of fetal membranes, abortions, and intrauterine or systemic treatments were not included in the current study, the proportion of cows with SEND was reduced.

Regarding clinical endometritis, we found that $27 \%$ of cows were affected. Surprisingly, not all the cows having clinical endometritis showed evidence of cytological inflammation (22\% of cows with VD-1 and $34 \%$ of those having VD-2). Therefore, these cows were false positives for clinical endometritis. A possible explanation for this interesting finding could be that manual examination of the vagina with a gloved hand does not allow differentiating the origin of the detected pus: vagina versus uterus. So, the purulent discharge of these animals could have originated from cervical or vaginal inflammation instead of uterine inflammation (Dubuc et al., 2010; Madoz et al., 2010; McDougall et al., 2011; Machado et al., 2012). This result is in agreement with a recent paper reporting 17 and $29 \%$ false positives for clinical endometritis diagnosed by vaginoscopy, considering threshold values of 5 and $18 \%$, respectively, as indicative for endometrial inflammation (Westermann et al., 2010). Also, another study found that only 36 and $38 \%$ of cows with clinical endometritis had cytological endometritis at 35 and $56 \mathrm{~d}$ after parturition, respectively (Dubuc et al., 2010).

\section{CONCLUSIONS}

As a low degree of agreement existed between the diagnostic outputs of uterine biopsy and cytology, this technique would not seem useful for the diagnosis of SEND. Nevertheless, fertility trials using uterine biopsies to predict pregnancy outcomes are needed to determine its diagnostic usefulness. Finally, bacteriology is not recommended as a diagnostic tool because no bacteria highly associated with uterine diseases were isolated from cows with SEND.

\section{ACKNOWLEDGMENTS}

This study was financed by a grant to R. L. de la Sota (V11/200; Proyecto de Incentivos, Universidad 
Nacional de La Plata, La Plata, Argentina). The authors thank the dairy farm owner and personnel for their help and support during the study.

\section{REFERENCES}

Allison, P. 1999. Logistic Regression Using SAS: Theory and Applications. SAS Institute Inc., Cary, NC.

Barański, W., M. Podhalicz-Dzięgielewska, S. Zduńczyk, and T. Janowski. 2012. The diagnosis and prevalence of subclinical endometritis in cows evaluated by different cytologic thresholds. Theriogenology 78:1939-1947.

Barlund, C. S., T. D. Carruthers, C. L. Waldner, and C. W. Palmer. 2008. A comparison of diagnostic techniques for postpartum endometritis in dairy cattle. Theriogenology 69:714-723.

Bicalho, M. L., V. S. Machado, G. Oikonomou, R. O. Gilbert, and R. C. Bicalho. 2012. Association between virulence factors of Escherichia coli, Fusobacterium necrophorum, and Arcanobacterium pyogenes and uterine diseases of dairy cows. Vet. Microbiol. 157:125-131.

Bicalho, R. C., V. S. Machado, M. L. Bicalho, R. O. Gilbert, A. G. Teixeira, L. S. Caixeta, and R. V. Pereira. 2010. Molecular and epidemiological characterization of bovine intrauterine Escherichia coli. J. Dairy Sci. 93:5818-5830.

Buergelt, C. 1997. Diseases of the female reproductive tract. Page 128 in Color Atlas of Reproductive Pathology of Domestic Animals. Mosby, St. Louis, MO.

Chapwanya, A., K. G. Meade, M. L. Doherty, J. J. Callanan, J. F. Mee, and C. O'Farrelly. 2009. Histopathological and molecular evaluation of Holstein-Friesian cows postpartum: Toward an improved understanding of uterine innate immunity. Theriogenology 71:1396-1407.

Chapwanya, A., K. G. Meade, F. Narciandi, P. Stanley, J. F. Mee, M. L. Doherty, J. J. Callanan, and C. O'Farrelly. 2010. Endometrial biopsy: A valuable clinical and research tool in bovine reproduction. Theriogenology 73:988-994.

Dubuc, J., T. F. Duffield, K. E. Leslie, J. S. Walton, and S. J. LeBlanc. 2010. Definitions and diagnosis of postpartum endometritis in dairy cows. J. Dairy Sci. 93:5225-5233.

Ferguson, J. D., D. T. Galligan, and N. Thomsen. 1994. Principal descriptors of body condition score in Holstein cows. J. Dairy Sci. 77:2695-2703.

Galvão, K. N., M. Frajblat, S. B. Brittin, W. R. Butler, C. L. Guard, and R. O. Gilbert. 2009. Effect of prostaglandin $\mathrm{F}_{2 \alpha}$ on subclinical endometritis and fertility in dairy cows. J. Dairy Sci. 92:49064913.

Gilbert, R. O., S. T. Shin, C. L. Guard, and H. N. Erb. 1998. Incidence of endometritis and effects on reproductive performance of dairy cows. Theriogenology 49:251. (Abstr.)

Gilbert, R. O., S. T. Shin, C. L. Guard, H. N. Erb, and M. Frajblat. 2005. Prevalence of endometritis and its effects on reproductive performance of dairy cows. Theriogenology 64:1879-1888.

Griffin, J. F., P. J. Hartigan, and W. R. Nunn. 1974. Non-specific uterine infection and bovine fertility. I. Infection patterns and endometritis during the first seven weeks post-partum. Theriogenology 1:91-106.

Hammon, D. S., I. M. Evjen, T. R. Dhiman, J. P. Goff, and J. L. Walters. 2006. Neutrophil function and energy status in Holstein cows with uterine health disorders. Vet. Immunol. Immunopathol. $113: 21-29$.

Jeremejeva, J., T. Orro, M. Valdmann, and K. Kask. 2010. Bacteriological and cytological findings during the late puerperal period after two different treatments of retained placenta followed by acute puerperal metritis. Acta Vet. Scand. 52:41.

Kasimanickam, R., T. F. Duffield, R. A. Foster, C. J. Gartley, K. E. Leslie, J. S. Walton, and W. H. Johnson. 2004. Endometrial cytology and ultrasonography for the detection of subclinical endometritis in postpartum dairy cows. Theriogenology 62:9-23.

Kasimanickam, R., T. F. Duffield, R. A. Foster, C. J. Gartley, K. E. Leslie, J. S. Walton, and W. H. Johnson. 2005. A comparison of the cytobrush and uterine lavage techniques to evaluate endometrial cytology in clinically normal postpartum dairy cows. Can. Vet. J. 46:255-259.

Kenney, R. M. 1978. Cyclic and pathologic changes of the mare endometrium as detected by biopsy, with a note on early embryonic death. J. Am. Vet. Med. Assoc. 172:241-262.

Machado, V. S., W. A. Knauer, M. L. S. Bicalho, G. Oikonomou, R. O. Gilbert, and R. C. Bicalho. 2012. A novel diagnostic technique to determine uterine health of Holstein cows at 35 days postpartum. J. Dairy Sci. 95:1349-1357.

Madoz, L. V., R. L. De la Sota, K. Suzuki, W. Heuwieser, and M. Drillich. 2010. Use of hysteroscopy for the diagnosis of postpartum clinical endometritis in dairy cows. Vet. Rec. 167:142-143.

Madoz, L. V., M. J. Giuliodori, M. Jaureguiberry, J. Plöntzke, M. Drillich, and R. L. de la Sota. 2013. The relationship between endometrial cytology during estrous cycle and cutoff points for the diagnosis of subclinical endometritis in grazing dairy cows. J. Dairy Sci. 96:4333-4339.

McDougall, S., H. Hussein, D. Aberdein, K. Buckle, J. Roche, C. Burke, M. Mitchell, and S. Meier. 2011. Relationships between cytology, bacteriology and vaginal discharge scores and reproductive performance in dairy cattle. Theriogenology 76:229-240.

Meira, E. B. S., Jr., L. C. S. Henriques, L. R. M Sá, and L. Gregory. 2012. Comparison of ultrasonography and histopathology for the diagnosis of endometritis in Holstein-Friesian cows. J. Dairy Sci. 95:6969-6973.

Messier, S., R. Higgins, Y. Couture, and M. Morin. 1984. Comparison of swabbing and biopsy for studying the flora of the bovine uterus. Can. Vet. J. 25:283-288.

Oral, H., M. Sozmen, G. Serin, and S. Kaya. 2009. Comparison of the cytobrush technique, vaginoscopy and transrectal ultrasonography methods for the diagnosis of postpartum endometritis in cows. J. Anim. Vet. Adv. 8:1252-1255.

Petit, T., J. Spergser, R. Rosengarten, and J. Aurich. 2009. Prevalence of potentially pathogenic bacteria as genital pathogens in dairy cattle. Reprod. Domest. Anim. 44:88-91.

Plöntzke, J., L. V. Madoz, R. L. De la Sota, M. Drillich, and W. Heuwieser. 2010. Subclinical endometritis and its impact on reproductive performance in grazing dairy cattle in Argentina. Anim. Reprod. Sci. 122:52-57.

Raab, D., M. Drillich, and W. Heuwieser. 2004. Diagnosis of subclinical endometritis and its effects on reproductive performance. Page 166 in Proc. 36th Annual Conference of the AABP, Columbus, OH. American Association of Bovine Practitioners, Auburn, AL.

Ribeiro, E. S., F. S. Lima, L. F. Greco, R. S. Bisinotto, A. P. Monteiro, M. Favoreto, H. Ayres, R. S. Marsola, N. Martinez, W. W. Thatcher, and J. E. Santos. 2013. Prevalence of periparturient diseases and effects on fertility of seasonally calving grazing dairy cows supplemented with concentrates. J. Dairy Sci. 96:5682-5697.

Rondon, M. R., P. R. August, A. D. Bettermann, S. F. Brady, T. H. Grossman, M. R. Liles, K. A. Loiacono, B. A. Lynch, I. A. MacNeil, C. Minor, C. L. Tiong, M. Gilman, M. S. Osburne, J. Clardy, J. Handelsman, and R. M. Goodman. 2000. Cloning the soil metagenome: A strategy for accessing the genetic and functional diversity of uncultured microorganisms. Appl. Environ. Microbiol. $66: 2541-2547$.

Rutter, B., A. F. Russo, and E. F. Capdevielle. 1999. Aislamientos bacterianos en hembras bovinas lecheras con partos normales y asistidos con distintos trastornos puerperales. Vet. Argent. 16:731-739.

Santos, T. M., and R. C. Bicalho. 2012. Diversity and succession of bacterial communities in the uterine fluid of postpartum metritic, endometritic and healthy dairy cows. PLoS ONE 7:e53048.

Santos, T. M. A., L. S. Caixeta, V. S. Machado, A. K. Rauf, R. O. Gilbert, and R. C. Bicalho. 2010. Antimicrobial resistance and presence of virulence factor genes in Arcanobacterium pyogenes isolated from the uterus of postpartum dairy cows. Vet. Microbiol. 145:84-89.

Santos, T. M. A., R. O. Gilbert, and R. C. Bicalho. 2011. Metagenomic analysis of the uterine bacterial microbiota in healthy and metritic postpartum dairy cows. J. Dairy Sci. 94:291-302. 
Sheldon, I. M., D. E. Noakes, A. N. Rycroft, and H. Dobson. 2002. Effect of postpartum manual examination of the vagina on uterine bacterial contamination in cows. Vet. Rec. 151:531-534.

Sheldon, I. M., A. N. Rycroft, B. Dogan, M. Craven, J. J. Bromfield, A. Chandler, M. H. Roberts, S. B. Price, R. O. Gilbert, and K. W. Simpson. 2010. Specific strains of Escherichia coli are pathogenic for the endometrium of cattle and cause pelvic inflammatory disease in cattle and mice. PLoS ONE 5:e9192.

Silva, E., S. Leitão, T. Tenreiro, C. Pomba, T. Nunes, L. Lopes da Costa, and L. Mateus. 2009. Genomic and phenotypic characterization of Escherichia coli isolates recovered from the uterus of puerperal dairy cows. J. Dairy Sci. 92:6000-6010.

Studer, E., and D. Morrow. 1978. Postpartum evaluation of bovine reproductive potential: Comparison of findings from genital tract examination per rectum, uterine culture, and endometrial biopsy. J. Am. Vet. Med. Assoc. 172:489-494.

Trigo Tavera, F. J. 1998. Patología sistemática veterinaria. 3rd ed. McGraw-Hill Interamericana, Santa Fé, México.
Werner, A., V. Suthar, J. Plöntzke, and W. Heuwieser. 2012. Relationship between bacteriological findings in the second and fourth weeks postpartum and uterine infection in dairy cows considering bacteriological results. J. Dairy Sci. 95:7105-7114.

Westermann, S., M. Drillich, T. B. Kaufmann, L. V. Madoz, and W. Heuwieser. 2010. A clinical approach to determine false positive findings of clinical endometritis by vaginoscopy by the use of uterine bacteriology and cytology in dairy cows. Theriogenology 74:1248-1255.

Williams, E. J., D. P. Fischer, D. U. Pfeiffer, G. C. England, D. E. Noakes, H. Dobson, and I. M. Sheldon. 2005. Clinical evaluation of postpartum vaginal mucus reflects uterine bacterial infection and the immune response in cattle. Theriogenology 63:102-117.

Winn, W., Jr., S. Allen, W. Janda, E. Koneman, G. Procop, P. Schreckenberger, and G. Woods. 2006. Koneman's Color Atlas and Textbook of Diagnostic Microbiology. 6th ed. Lippincott Williams and Wilkins, Philadelphia, PA. 